\title{
HUBUNGAN TINGKAT PENGETAHUAN KESELAMATAN PASIEN TERHADAP KINERJA PERAWAT
}

\author{
Fara Diba Salsabila Harahap
}

\section{Email : salsabilaharahapfaradiba@gmail.com}

\section{Latar Belakang}

Keselamatan pasien atau patient safety merupakan sistem pelayanan rumah sakit yang memberikan asuhan pasien secara lebih aman dan merupakan prinsip dasar perawatan kesehatan di lembaga kesehatan yang terus membutuhkan peningkatan kualitas. Yang didalamnya terdapat assessmen risiko, identifikasi dan pengelolaan risiko pada pasien, pelaporan dan juga analisis suatu insiden, kemampuan belajar dari insiden dan tindak lanjutnya, serta implementasi solusi untuk mengurangi timbulnya risiko dan mencegah terjadi cedera yang disebabkan oleh kesalahan perawat akibat melakukan suatu tindakan atau tidak mengambil tindakan yang dimana seharusnya diambil atau dilakukan. Faktor paling penting dalam memastikan keselamatan pasien merupakan kualitas keperawatan (Wijaya et al., 2016).

Pengetahuan adalah hasil dari tahu, dan hal ini terjadi setelah seseorang melakukan pengindraan terhadap suatu objek tertentu. Pengindraan terjadi melalui panca indra manusia, yaitu indra penglihatan, pendengaran, dan penciuman, serta perasa dan peraba. Tetapi sebagian besar dari pengetahuan manusia didapat melalui mata dan telinga. Dalam lingkup keselamatan pasien, pengetahuan seorang perawat merupakan suatu hal yang berhubungan dengan komitmen yang sangat diperlukan dalam upaya membangun budaya keselamatan pasien (Wijaya et al., 2016).

Kinerja merupakan suatu hasil yang dicapai atau prestasi yang dicapai karyawan dalam melaksanakan suatu pekerjaan dalam suatu organisasi (Wibowo, 2011). Pada rumah sakit sendiri pencapaian kinerja dapat dilihat dari beberapa aspek pelayanan. Salah satunya ialah kinerja pelaksanaan keselamatan pasien. Perawat ialah pejabat eksekutif kesehatan yang dimana bekerja dengan waktu tertinggi yaitu memberikan 24 jam pelayanan terus-menerus serta harus berkolaborasi dengan tim kesehatan lain dan maka dari itu, dapat menyebabkan 
atau berisiko terjadinya insiden keselamatan pasien.

Selain itu, perawat juga memiliki peran yang sangat penting dalam pencegahan terjadinya kesalahan pada pengobatan, termasuk pelaporan insiden, mendidik diri sendiri maupun orang lain. Sebagai tenaga kesehatan, seorang perawat memiliki sejumlah peran dalam menjalankan tugasnya sesuai dengan hak dan kewenangan yang dimiliki oleh perawat. Peran perawat yang paling utama adalah sebagai pelaksana, pengelola, pendidik serta peneliti .

\section{Metode}

Metode yang digunakan dalam penulisan ini yaitu menggunakan literature riview atau studi pustaka berdasarkan teks book, jurnal dan berfokus pada Hubungan Tingkat Pengetahuan Keselamatan Pasien Terhadap Kinerja Perawat, yang dimana untuk menegetahui kinerja perawat sesuai tingkat pengetahuannya. Dengan cara menganalisis, eksplorasi sumber dan kajian bebas. Adapun sumber kajian yang digunakan ialah 10 tahun terakhir.

\section{Hasil}

Hasil dari literature review ini didapatkan bahwa terdapat hubungan antara pengetahuan seorang perawat dalam menerapkan keselamatan pasien.
Keselamatan pasien di rumah sakit selalu menjadi isu penting karena begitu banyaknya kasus medical error yang terjadi di berbagai negara belahan dunia. Seperti di Negara Amerika Serikat kesalahan medis yang terjadi tepat di seluruh spektrum, dan dapat pula dikaitkan dengan sistem dan faktor manusia. Insiden keamanan buruk yang paling umum terkait dengan prosedur bedah $(27 \%)$, dan kesalahan pengobatan (18,3\%) serta infeksi terkait perawatan kesehatan (12,2\%) (Who, 2017). Ministry Of Health Malaysia 2013 menyatakan bahwa angka insiden keselamatan pasien dalam rentang waktu Januari hingga Desember 2013, sebanyak 2.769 kejadian dan untuk negara Indonesia sendiri dalam rentang waktu 2006 sampai 2011 KKPRS melaporkan terdapat 877 kejadian keselamatan pasien (RSUDZA, 2017). Data insiden keselamatan pasien tahun 2012 juga melaporkan analisis penyebab terjadinya insiden $46 \%$ berkaitan dengan salah identifikasi, $36 \%$ dikarenakan karena komunikasi yang tidak efektif sehingga terjadi medication error pada pasien, $18 \%$ dikarenakan prosedur tidak dijalankan (Fatimah, Sulistiarini and Ata, 2018).

Terdapat hubungan positif yang ditunjukkan oleh hasil uji statistik dimana hasil tersebut menggambarkan bahwa semakin tinggi nilai skor yang diperoleh 
untuk tingkat pengetahuan perawat mengenai keselamatan pasien, maka semakin tinggi pula nilai skor yang diperoleh untuk kinerja perawat dalam keselamatan pasien. Terdapatnya hubungan antara tingkat pengetahuan perawat mengenai patient safety dengan kinerja perawat, sejalan dengan teori perilaku Lawrence Green yang menyebutkan bahwa pengetahuan termasuk dalam faktor predisposisi yang akan mempengaruhi praktik kesehatan seseorang.

Kinerja penerapan keselamatan pasien oleh perawat dapat dipengaruhi dari faktor- faktor yang mempengaruhi kinerja perawat itu sendiri. Dari teori kinerja yang dikemukakan oleh Gibson, bahwa faktorfaktor yang mempengaruhi kinerja itu ada tiga variabel yakni ; variabel individu, variabel psikologi dan variabel organisasi. Cara yang dapat dilakukan untuk memastikan keamanan suatau tindakan bedah yang benar letak adalah dengan meminta dokter untuk menandai lokasi operasi berupa lingkaran kecil. Pencegahan risiko infeksi dapat diupayakan dengan cara mencuci tangan pada five moment. Serta upaya yang dilakukan untuk mencegah risiko jatuh adalah dengan melakukan pengkajian risiko jatuh dan melakukan intervensi pencegahan kejadian jatuh.

\section{Pembahasan}

Terdapat berbagai macam cara yang digunakan untuk memperoleh kebenaran pengetahuan sepanjang sejarah, yaitu:

\section{Cara Coba Salah (Trial and Error)}

Cara ini dilakukan dengan menggunakan kemungkinan tidak berhasil, dan dicoba kemungkinan yang lain. Apabila tidak berhasil juga, maka akan dicoba kemungkinan yang lainnya lagi sampai mendapatkan hasil yang mencapai kebenaran.

\section{Cara Kekuasaan atau Otoritas}

Pengetahuan diperoleh berdasarkan pada kekuasaan baik tradisi, otoritas pemerintahan, otoritas pemimpin agama, maupun ahli ilmu pengetahuan.

\section{Berdasarkan Pengalaman Pribadi}

Hal ini dilakukan dengan cara mengulang kembali pengalaman yang didapat dalam memecahkan permasalahan yang dihadapi pada masa lalu.

\section{Melalui Jalan Pikiran}

Melalui jalan pikiran manusia telah mampu menggunakan penalarannya dalam memperoleh suatu pengetahuannya. Dengan kata lain, untuk memperoleh 
kebenaran pengetahuan, manusia telah menggunakan jalan pikirannya.

5. Cara baru atau modern

Dalam memperoleh pengetahuan pada orang dewasa lebih sistematis, logis, dan ilmiah. Cara ini disebut metode penelitian ilmiah.

Faktor-Faktor yang mempengaruhi pengetahuan adalah :

a) Pendidikan

Hal ini sejalan dengan yang dikemukakan (Handoko, 2009) menyatakan bahwa pendidikan merupakan faktor penting dalam menentukan kemampuan kerja seseorang. Oleh karena itu pendidikan adalah langkah awal untuk melihat kemampuan seseorang. (Notoatmodjo, 2012) menyatakan bahwa hal lain yang dapat mempengaruhi pengetahuan adalah tingkat pendidikan. Semakin tinggi pengetahuan seseorang maka akan semakin baik pula pengetahuan yang dimiliki orang tersebut. Namun perlu ditekankan bahwa seseorang yang berpendidikan rendah tidak berarti mutlak berpengetahuan rendah pula karena kemampuan belajar yang dimiliki juga dapat mempengaruhi pengetahuan, dengan kemampuan belajar yang baik seseorang akan cenderung mendapatkan informasi yang lebih banyak, baik dari orang lain maupun dari media massa.

b) Pengalaman bekerja

Khususnya pengalaman kerja perawat, Hal ini didukung oleh penelitian yang dilakukan (Ranupandojo, 2010) yang menyatakan bahwa lama kerja terkait dengan masa kerja, semakin lama seseorang bekerja pada suatu organisasi maka semakin berpengelaman orang tersebut sehingga kecakapan kerjanya semakin baik. Hal ini sesuai dengan pendapat (Notoatmodjo, 2012) yang menyatakan bahwa pengetahuan seseorang akan berubah seiring dengan setiap hal yang dialami seseorang selama bertahuntahun dan pengetahuan diperoleh dari pengalaman sendiri atau orang lain yang melibatkan apa yang dialami oleh panca indra.

c) Sosialisasi

Menurut David A. Goslin (2013) dalam penelitiannya mengatakan bahwasannya Sosialisasi ialah proses belajar yang dialami seseorang untuk memperoleh pengetahuan, keterampilan, nilai-nilai dan norma-norma agar dapat berpartisipasi dalam lingkungan kerjanya. Peningkatan pengetahuan tidak mutlak diperoleh pendidikan formal, akan tetapi juga dapat diperoleh pada pendidikan non formal seperti didapat dari seminar atau 
pelatihan serta mencari informasi dari media massa seperti internet, buku, televisi (Notoatmodjo, 2012).

d) Usia

Usia berpengaruh terhadap daya tangkap dan pola pikir seseorang. Semakin bertambah usia seseorang, akan semakin berkembang pula daya tangkap dan pola pikirnya, sehingga pengetahuan yang diperolehnya semakin membaik.

Seorang perawat dalam memberikan asuhan keperawatan harus memiliki pengetahuan yang benar, keterampilan, dan sikap untuk menangani kompleksitas perawatan kesehatan. Tanpa pengetahuan yang memadai, tenaga kesehatan termasuk perawat tidak bisa menerapkan dan mempertahankan budaya keselamatan pasien (Myers, 2012). Dengan demikian dapat dijelaskan bahwa semakin tinggi pengetahuan perawat tentang penerapan keselamatan pasien (patient safety), diharapkan semakin tinggi pula perawat dalam memahami pentingnya penerapan keselamatan pasien (patient safety) yang diberikan kepada pasien dalam pelayanan keperawatan (Darliana, 2016). Insiden Keselamatan Pasien (IKP) yang terdiri dari Kejadian Tidak Diharapkan (KTD), Kejadian Nyaris Cedera (KNC), Kejadian Tidak Cedera
(KTC) dan Kondisi Potensial Cedera (KPC).

Masalah keselamatan pasien dari berbagai jenis terjadi selama pelayanan kesehatan berlangsung. Termasuk kesalahan transfusi dan efek samping obat, salah operasi dan luka bedah, pengendalian terkait cedera atau kematian, infeksi terkait perawatan rumah sakit, jatuh, luka bakar, ulkus decubitus, dan kesalahan identitas pasien. Terdapat 6 tujuan utama penanganan pasien dengan penerapan keselamatan pasien (patient safety) menurut PERMENKES RI No 1691 yeng berpedoman pada Joint Commision International, yaitu :

1) Mengidentifikasi atau mendiagnosa pasien dengan benar

Yang dimaksud ialah untuk melakukan dua kali pengecekan, yaitu : pertama, untuk identifikasi pasien sebagai individu yang akan menerima pelayanan atau pengobatan; dan kedua, untuk kesesuaian pelayanan atau pengobatan terhadap individu tersebut.

2) Meningkatkan komunikasi secara efektif

Komunikasi efektif, yang tepat waktu, akurat, lengkap, jelas dan yang dapat dipahami oleh pasien akan mengurangi 
kesalahan, dan menghasilkan peningkatan keselamatan pasien.

3) Meningkatkan keamanan dari highalert medication

Obat-obatan yang perlu diwaspadai (high-alert medications) merupakan obat yang sering menyebabkan kesalahan atau kesalahan serius. Kesalahan dapat terjadi bila perawat tidak mendapatkan orientasi yang baik dan dalam situasi darurat.

4) Memastikan bahwa benar tempat, benar prosedur dan benar pembedahan pasien.

Salah lokasi, salah prosedur, pasien salah pada operasi, adalah sesuatu yang sangat mengkhawatirkan dan tidak jarang terjadi di rumah sakit.

5) Mengurangi infeksi dari pekerja kesehatan

Infeksi biasanya dijumpai dalam semua bentuk pelayanan kesehatan termasuk infeksi saluran kemih, infeksi pada aliran darah (bloodstream infections) dan pneumonia (sering kali dihubungkan dengan ventilasi mekanis).

6) Mengurangi terjadinya risiko jatuh pada pasien

Jumlah kasus jatuh pada pasien cukup bermakna sebagai penyebab cedera bagi pasien rawat inap. Perlunya keselamatan

pasien (patient safety) diterapkan pada tindakan medis, dikarenakan kompleksnya rangkaian tindakan medis yang kerap dilakukan. Dimulai dengan diagnosa, pertolongan pertama, pemeriksaan laboratorium, pemberian obat hingga tindakan pembedahan yang memungkinkan terjadinya kesalahankesalahan medis.

WHO (2007) memperkenalkan tata cara penanganan untuk menjamin keselamatan pasien yang dikenal dengan Nine Patient Safety Solutions (9-PSS), yaitu:

- Melihat-sama, menyebut-sama tentang nama obat.

- Identifikasi pasien dengan benar.

- Komunikasi saat pasien berpindah tangan.

- Benar prosedur benar bagian tubuh.

- Kontrol kosentrasi cairan dan elektrolit.

- Ketelitian pengobatan saat peralihan perawatan.

- Menghindari chateter dan selang tersumbat atau tidak tersambung.

- Penggunaan alat suntik sekali pakai.

- Menjaga kebersihan tangan untuk pencegahan infeksi

\section{Penutup}


Keselamatan pasien atau patient safety merupakan sistem pelayanan rumah sakit yang memberikan asuhan pasien secara lebih aman dan merupakan prinsip dasar perawatan kesehatan di lembaga kesehatan yang terus membutuhkan peningkatan kualitas. Dalam lingkup patient safety pengetahuan perawat merupakan hal yang berhubungan dengan komitmen yang sangat diperlukan dalam upaya membangun budaya keselamatan pasien (Wijaya et al., 2016). Faktor-Faktor yang mempengaruhi pengetahuan adalah pendidikan,pengalaman

bekerja,sosialisasi,usia. Seorang perawat dalam memberikan asuhan keperawatan harus memiliki pengetahuan yang benar, keterampilan, dan sikap untuk menangani kompleksitas perawatan kesehatan. Tanpa pengetahuan yang memadai, tenaga kesehatan termasuk perawat tidak bisa menerapkan dan mempertahankan budaya keselamatan pasien (Myers, 2012).

\section{Daftar Pustaka}

Arini.D,dkk. (2019). Hubungan Tingkat Pengetahuan Perawat Tentang Identifikasi dalam Patient Safety dengan Pelaksanaannya di Ruang Rawat Inap RSUD SK. Lerik Kupang. Jurnal Ilmiah Keperawatan Stikes Hang Tuah Surabaya, Vol.14 No. 2.
Darliana, D. (2016) . Hubungan Pengetahuan Perawat Dengan Upaya Penerapan Patient Safety di Ruang Rawat Inap Rumah Sakit Umum Daerah DR.Zainoel Abidin Banda Aceh. Idea Nursing Journal, VII(1), pp. 61-69.

Herawati.Y.T. (2015).Budaya Keselamatan Pasien di Ruang Rawat Inap Rumah Sakit X Kabupaten Jember ( Patient Safety Culture Inpatient In The Hospital X District Jember) . Jurnal IKESMA Volume 11 Nomor 1.: 52-60.

Isnaini.N.M, Rofii.M. (2014). Pengalaman Perawat Pelaksana dalam Menerapkan Keselamatan Pasien. Jurnal Managemen Keperawatan . Volume 2, No. $1 ; 30-37$.

Jaladara.V, Jayanti.S, Ekawati . (2015). Hubungan Tingkat Pengetahuan dan Praktik Perawat Mengenai Keselamatan Pasien ( Patient safety) di Instalasi Gawat Darurat RS X Semarang. Jurnal Kesehatan Masyarakat (e-Journal) Volume 3, Nomor 1,: 462-472.

Kamil.H . (2010). Patient Safety. Idea Nursing Journal.Vol. I No. 1.:1-8.

Kemenkes. (2017). Peraturan Menteri Kesehatan Republik Indonesia No 11 
Tahun 2017 tentang Keselamatan Pasien.

Sari .D.K, dkk. (2015). Hubungan Karakteristik dan Peran Perawat dengan Tindakan Keselamatan Pasien dalam Pemasangan Infus. Jurnal Kesehatan Volume 10 No. 1,: 177 122.

Simamora, R. H. (2018). Buku ajar keselamatan pasien melalui timbang terima pasien berbasis komunikasi efektif : SBAR. Medan: USUpress.

Simamora, R. H. (2020). Learning of Patient Identification in Patient Safety
Programs Through Clinical Preceptor Models. Medico Legal Update, 20(3), 553-556.

Suci.W.P. ( 2018) . Peningkatan Budaya Keselamatan Pasien Melalui Pemberdayaan Champion

Keselamatan Pasien. JKH, Volume 2 Nomor 2 : 23-39.

Wijaya, H. et al. (2016). Tingkat pengetahuan perawat tentang Patient Safety di rumah sakit Adi Husada Surabaya., 2(1), pp. 68-74. 